Editorial

\title{
Zika Virus Outbreak and the Poor Brazilian Family Planning Program
}

\section{A epidemia de Zika e a insuficiência do programa de planejamento familiar no Brasil}

\author{
Milena Bastos Brito ${ }^{1}$ Ian S. Fraser ${ }^{2}$ \\ ${ }^{1}$ Escola Bahiana de Medicina e Saúde Pública, Salvador, BA, Brazil \\ 2 University of New South Wales, School of Women's and Children's \\ Health and Royal Hospital for Women, Sydney, Australia \\ Rev Bras Ginecol Obstet 2016;38:583-584.
}

The National Family Planning Policy was created in Brazil in 2007. It includes offering eight free contraceptive methods (intrauterine device [IUD] with copper, progestogen-only pill, combined pill, monthly injectable, depot medroxyprogesterone, diaphragm, male and female condoms) and also some other oral and injectable contraceptives at reduced prices at "popular" pharmacies. In the last decades, modern contraceptive methods have been developed, such as levonorgestrel intrauterine system (IUS) and subdermal implants, but these are not accessible to the majority of the Brazilian population because they are not available (for free or at a low cost) in the national health system. ${ }^{1}$

In 2015, a microcephaly outbreak began among Brazilian newborns, probably associated with the Zika virus. Brazilian authorities estimate that $\sim 1,5$ million cases of Zika infection have occurred since the outbreak began, with almost 1,300 cases of microcephaly subsequent to prenatal infection during pregnancy. ${ }^{2}$ Although initially concentrated in the Northeast of Brazil, the virus has spread throughout South America, the Caribbean and Puerto Rico. A published case series $^{3}$ of 1,511 live newborn infants with suspected Zika virus infection occurred during pregnancy showed a sensitivity of $83 \%$ for microcephaly for diagnostic detection. However there are Publications that Added additional clinical characteristics, including severe intracranial calcifications, severe cortical malformations, ventriculomegaly, cerebellar hypoplasia, and abnormal hypodensity of the white matter, but with normal head circumference, creating a necessary expansion of the concept to become congenital Zika virus syndrome. $^{4}$

In times of Zika virus outbreak and its fetal/neonatal effects, the World Health Organization underlined the importance of affected countries to offer universal access to family planning services. Margaret Chan, Director-General of
Address for correspondence Milena Bastos Brito, MD, PhD, Av. D. João VI, 275, Salvador, BA, Brazil (e-mail: milenabrito@ bahiana.edu.br).
DOI http://dx.doi.org/ 10.1055/s-0036-1593411. ISSN 0100-7203. the World Health Organization, said "Latin America and the Caribbean have the highest proportion of unwanted pregnancies in the world. In addition, these countries have high rates of sexual violence, and restrictions on the use of emergency contraception and safe abortion prohibited by law." Therefore, the recommendation of health authorities for women residing in these regions to postpone pregnancy for $1-2$ years is unlikely to be achieved. ${ }^{5}$

The Centers for Disease Control and Prevention (CDC) recommend that people residing in areas with current active Zika virus transmission might seriously consider delaying their next pregnancy and, that women who have confirmed Zika virus disease should wait at least 8 weeks after symptom onset before attempting conception. Men with Zika virus disease should wait at least 6 months after symptom onset before attempting conception. Women and men with possible exposure to Zika virus, but without clinical illness consistent with Zika virus disease should wait at least 8 weeks after exposure before attempting conception. Health care providers should discuss strategies to prevent unintended pregnancy, including use of the most effective contraceptive methods. ${ }^{6}$

The most cost-effective contraceptive methods are the long acting reversible ones, such as implants, IUD and IUS, because they are not user-dependent, have high rates of satisfaction and have very low failure rates (less than $1 \%$ versus around $9 \%$ in oral contraceptive pill users). ${ }^{7,8}$ In Brazil, only the IUD with cooper is available to the population at no charge, but it is still seldom used. In 2014, the Federação Brasileira das Associações de Ginecologia e Obstetrícia (FEBRASGO) presented a proposal to the Brazilian Ministry of Health for the inclusion of the levonorgestrel IUS and the etonogestrel implant for teenagers, but the proposal was rejected on the grounds of high cost. The

Copyright $\odot 2016$ by Thieme-Revinter Publicações Ltda, Rio de Janeiro, Brazil

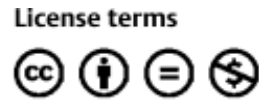


Brazilian Government would pay around US\$ 50 per implant (lasting up to 3 years) or levonorgestrel IUS (lasting up to 5 years). ${ }^{9}$ Undoubtedly, the Brazilian government is paying much more to treat the consequences of the Zika virus syndrome.

The CDC undertook a study on Puerto Rico's contraceptive needs. The authors concluded that local health policies were needed to ensure open access to effective contraception for women who desire to avoid pregnancy during the Zika outbreak in Puerto Rico and other affected areas. An increase of reimbursements and a reduction in costs for contraceptive services would support access. Efforts to increase opportunities and education concerning long acting reversible contraceptive method access are urgently needed. ${ }^{10}$ The rates of unplanned pregnancy in Brazil are similar to those of Puerto Rico, making these data and recommendations highly relevant also in Brazil.

The Zika virus outbreak has highlighted the poor quality of the national family planning programs in Brazil and others Latin American countries. The majority of the Brazilian women who are at risk for unplanned pregnancies live in areas with a high prevalence of the Zika virus. Therefore, in order to decrease adverse pregnancy and birth outcomes associated with Zika virus disease during pregnancy, crucial improvements need to be made in providing full access for all women in the reproductive years to family planning services and to long acting reversible contraceptive methods. ${ }^{11}$

\section{References}

1 Brasil. Ministério da Saúde [Internet]. Saúde sexual e saúde reprodutiva.2013. (Cadernos de Atenção Básica, 26) [cited on June 10, 2016]. Available at: http://bvsms.saude.gov.br/bvs/publicacoes/saude_sexual_saude_reprodutiva.pdf
2 Brasil. Ministério da Saúde do Brasil. Secretaria de Vigilância em Saúde. Monitoramento dos casos de dengue, febre de chikungunya e febre pelo vírus Zika até a Semana Epidemiológica 21, 2016. Bol Epidemiol [Internet]. 2016 [cited on May 30, 2016];47(27). Available at: http://portalsaude.saude.gov.br/images/pdf/2016/ junho/30/2016-021.pdf

3 França GV, Schuler-Faccini L, Oliveira WK, Henriques CM, Carmo EH, Pedi VD, et al. Congenital Zika virus syndrome in Brazil: a case series of the first 1501 live births with complete investigation. Lancet 2016;(16):30902-30903

4 França GV, Schuler-Faccini L, Oliveira WK, et al. Congenital Zika virus syndrome in Brazil: a case series of the first 1501 livebirths with complete investigation. Lancet 2016;388(10047):891-897

5 World Health Organization [Internet]. Sixty-ninth World Health Assembly opens in Geneva. 2016 [cited 2016 Jun 26]. Available from: http://www.who.int/mediacentre/news/releases/2016/sixtyninth-world-health-assembly-opens/en/

6 Petersen EE, Polen KN, Meaney-Delman D, et al. Update: Interim Guidance for Health Care Providers Caring for Women of Reproductive Age with Possible Zika Virus Exposure-United States, 2016. MMWR Morb Mortal Wkly Rep 2016;65(12):315-322

7 Winner B, Peipert JF, Zhao Q, et al. Effectiveness of long-acting reversible contraception. N Engl J Med 2012;366(21):1998-2007

8 Mavranezouli I; LARC Guideline Development Group. The costeffectiveness of long-acting reversible contraceptive methods in the UK: analysis based on a decision-analytic model developed for a National Institute for Health and Clinical Excellence (NICE) clinical practice guideline. Hum Reprod 2008;23(6):1338-1345

9 Brasil. Ministério da Saúde. Comissão Nacional de Incorporação de Tecnologias no SUS [Internet]. Recomendações sobre as tecnologias avaliadas.2016[citado 2016 Jun 30]. Disponível em: http://conitec.gov.br/decisoes-sobre-incorporacoes

10 Tepper NK, Goldberg HI, Bernal MI, et al. Estimating Contraceptive Needs and Increasing Access to Contraception in Response to the Zika Virus Disease Outbreak-Puerto Rico, 2016. MMWR Morb Mortal Wkly Rep 2016;65(12):311-314

11 Roa M. Zika virus outbreak: reproductive health and rights in Latin America. Lancet 2016;387(10021):843 